\title{
ECOLOGIA, CORPO E ESPIRITUALIDADE: uma etnografia das experiências de caminhada ecológica em um grupo de ecoturistas $^{1}$
}

\author{
Carlos Alberto Steil \\ Rodrigo Toniol ${ }^{*}$
}

\begin{abstract}
O presente trabalho tem como objeto de estudo a experiência dos ecocaminhantes, um grupo de praticantes de caminhadas ecológicas que, apostando no cultivo de um bem-estar físico, mental e espiritual, realiza caminhadas em meio à natureza. A partir da etnografia da experiência dos caminhantes, procura-se investigar a vivência das trilhas como lugares repletos de forças restauradoras, fluidos energéticos para saúde do corpo e da alma. Com base no esforço teórico de uma proposta que pretende, sobretudo, traduzir a fenomenologia para o campo antropológico e, assim, colapsar dicotomias como mente e corpo, natureza e cultura, sujeito e objeto, busca-se refletir sobre o caráter terapêutico das caminhadas, compreendidas pelos caminhantes não apenas como exercícios físicos, mas também como uma via de acesso às questões relativas à alma.

PALAVRAS-CHAVE: ecoturismo, nova era, corporeidade, corpo, caminhadas ecológicas
\end{abstract}

\section{INTRODUÇÃO}

Esta é uma etnografia sobre a experiência de caminhadas em um grupo de ecoturistas: o Ecocaminhantes, uma empresa de turismo ecológico que promove trilhas em meio à natureza. Procuramos identificar, na pesquisa, os pontos de convergência entre práticas ecológicas, de saúde e de espiritualidade voltadas para o aperfeiçoamento de si. O que está em jogo é apresentar, a partir da expe-

Doutor em Antropologia Social. Professor do Programa de Pós-Graduação em Antropologia Social da Universidade Federal do Rio Grande do Sul (UFRGS).

Instituto de Filosofia e Ciências Humanas, Departamento de Antropologia. Av. Bento Gonçalves, 9500 - Prédio 43311, Sala 104A -Agronomia. Cep: 91509-900 - Porto Alegre, RS - Brasil. steil.carlosalberto@gmail.com

** Mestrando em Antropologia Social pelo Programa de PósGraduação em Antropologia Social da Universidade Federal do Rio Grande do Sul (UFRGS). rodrigo.toniol@gmail.com

${ }^{1}$ Este artigo decorre da contribuição de Rodrigo Toniol ao projeto "O cultivo de Si nas paisgens da ecologia e do sagrado", coordenado por Carlos Alberto Steil e Isabel Carvalho (PUC-RS) e financiado pelo CNPq. Ao longo do texto, a flexão verbal varia entre a primeira e a terceira pessoa, por conta da participação de Carlos Alberto Steil em apenas algumas das experiências de campo e entrevistas citadas, enquanto Rodrigo Toniol participou de todas as idas a campo e entrevistas. Assim, a primeira pessoa do singular, usada no texto, refere-se sempre à experiência de Rodrigo Toniol. riência etnográfica das caminhadas, atravessamentos que compõem uma complexa trama de interesses, motivações, sentimentos e sensações próprias do ato de caminhar no contexto das peregrinações contemporâneas junto à natureza.

Alinhados com a proposta do paradigma da corporeidade de Thomas Csordas (2008), procuramos compor a narrativa etnográfica tomando como ponto de partida as experiências daqueles que caminham nas condições de sujeitos urbanos, escolarizados, religiosos ou não, defensores da causa ecológica ou indiferentes a ela. Trata-se, enfim, de explorar como as experiências da paisagem, do ambiente e do lugar em que se caminha estão articuladas com as práticas e pertencimentos cotidianos dos caminhantes. Assim, procuramos privilegiar a polifonia das experiências do caminhar, afastando-nos da imagem de uma caravana que se desloca em uma mesma direção, tanto objetiva como simbólicamente, e aproximando-nos de um olhar que enfoca essa prática como uma arena de disputas capaz de acolher tensões entre diferentes discursos, enunciados e sentidos.

A possibilidade de se estabelecer uma 
interface entre espiritualidade, ecologia e aperfeiçoamento de si, a partir de práticas que assumem como central a busca por uma vida saudável, sedimenta-se numa série de trabalhos (Carvalho, 2002; Carvalho; Steil, 2008; Magnani, 1999; Soares, 1994) que apontam para certa reordenação do panorama religioso que teria transformado, em alguns contextos, a relação com o sagrado. Alguns autores têm sugerido que determinadas atitudes responsáveis em relação ao meio ambiente têm conformado uma espécie de ascese ecológica, indicativa da incorporação de sistemas de crenças religiosas por parte de sujeitos e grupos ecologicamente orientados que, ao fim e ao cabo, terminam por promover uma espécie de sacralização da natureza. Um modelo analítico para se pensar experiências religiosas na natureza é o sugerido por Campbell (1997), que compreende esse processo como fruto do "espírito de um tempo", caracterizado, sobretudo, pela substituição do paradigma cultural e da teodiceia que tem sustentado as práticas e concepções ocidentais por um paradigma que comumente caracterizou o Oriente, o qual o autor denomina como “orientalização do Ocidente". O que é central nessa transformação é o deslocamento da noção ocidental de religião - tradicionalmente concebida como transcendente - para a de imanência, característica de concepções orientais.

Uma das consequências da "orientalização"

é a mudança no espaço ocupado por Deus, que deixa de ser situado em um plano fora do mundo e passa, aos poucos, a habitar "no mundo", tornando-se acessível por meio de experiências particulares de caráter místico e energético, fruto, especialmente, de um maior contato com a natureza. Refletir sobre essa mudança é, basicamente, realizar um esforço para compreender como a centralidade do sagrado foi dando lugar a uma experiência de sacralidade mais difusa, que tem a natureza como espaço privilegiado de manifestação (Carvalho; Steil, 2008). Em certa medida, é esse deslocamento do transcendente para o imanente que possibilita aos sujeitos conceberem a natureza como o lugar privilegiado do sagrado.

Essa centralidade atribuída ao sagrado ima- nente incorpora outra característica da modernidade religiosa que, segundo Hervieu-Léger (2008), nos remete à autonomia do indivíduo em compor seu próprio sistema de crenças. ${ }^{2}$ Essas características - da imanência e da autonomia permitem-nos situar a experiência religiosa no plano da experiência pessoal dos sujeitos, que se tornam o parâmetro de certificação da verdade. Ou seja, a certificação da verdade afasta-se das normalizações institucionalizadas e passa a ser atestada pelo próprio indivíduo - configurando o que temos denominado como religiões do self (Steil, 1999, 2004, 2006). Nesses contextos, as experiências dos sujeitos são os próprios princípios geradores de autenticidade da relação que se estabelece com o sagrado (Hervieu-Léger, 1993, 2008). Pretendemos, assim, sugerir que a modernidade secular, governada em sua base pela razão científica e técnica, ao mesmo tempo em que imprimiu uma marca a-religiosa no funcionamento da sociedade, também permitiu a emergência de uma verdadeira nuvem de novas crenças que encontram, nos corpos que se conectam com a natureza por meio de caminhadas, um de seus pontos de ancoragem.

Desse modo, sugerimos que as relações com o sagrado, vividas pelos sujeitos de nossa pesquisa, estão implicadas com as noções de um corpo saudável para os caminhantes. Ao que parece, diferentemente da experiência dos peregrinos tradicionais, que usavam seus corpos penitentes como instrumentos de perdão e salvação para transcender este mundo, os caminhantes que acompanhamos compreendem seus corpos como o lugar privilegiado de conexão com o mundo e principal meio de aperfeiçoamento de si. Por outro lado, se, nas peregrinações tradicionais, a busca da saúde física é uma dádiva divina, que pode ser concedida dentro de um regime de reciprocidade entre seres humanos e divinos, para os ecocaminhantes, alcançar o bem estar físico e a saúde é uma

${ }^{2}$ As religiões afro-brasileiras, por exemplo, apesar de considerarem os Orixás como entidades imanentes, não são, a princípio, religiões que compõem esse novo quadro de crenças que procuramos descrever. 
responsabilidade dos sujeitos humanos, que buscam se integrar num todo hamonioso que aponta para a superação das divisões entre corpo e alma, natureza e cultura.

Ao longo de um ano e meio de trabalho de campo - iniciado em fevereiro de 2008 e finalizado em novembro de 2009-, realizei dez caminhadas, participei de diversas reuniões dedicadas a elaborar roteiros, confraternizações para receber caminhantes regressos de longas viagens e festas de despedidas. ${ }^{3}$ Pude eu mesmo, depois de muitos desconfortos musculares, desânimos e frustrações traduzidas na minha incapacidade física em realizar mais que uma caminhada por mês, confrontar-me com o meu próprio corpo, com os limites físicos que ele me impunha e, com isso, aproximar-me da prática de caminhadas a partir da reflexão sobre o modo pelo qual minhas próprias experiências corporais foram sendo padronizadas naquela prática. Para pesquisar caminhantes, fui convocado a caminhar, a engajar meu corpo naquele contexto etnográfico e concebê-lo não apenas como objeto para reflexão, mas também como instrumento analítico. No que diz respeito à produção da narrativa etnográfica, isso implica expor também minhas próprias experiências, expectativas e sensibilidades ao caminhar. Foi somente assim que pude tomar o corpo como diretriz metodológica deste trabalho, concebendo-o "não como um objeto que é bom para pensar, mas como um sujeito que é necessário para ser" (Csordas, 2008, p. 367).

Realizar caminhadas com os ecocaminhantes não apenas conduziram-nos a cultivar hábitos relacionados ao condicionamento físico, como também a nos inteirar de um vasto repertório de destinos frequentemente percorridos por esses sujeitos. Tivemos de estudar os destinos mais comuns de caminhadas, para conversar com nossos interlocutores sobre os trajetos mais bonitos, os mais longos, os mais difíceis. Passamos a participar de listas de dis-

${ }^{3}$ Como foi explicitado no início deste artigo, o parágrafo que segue retrata a experiência de Rodrigo, que realizou todas as caminhadas. A reflexão metodológica que permeia a narrativa na primeira pessoa foi realizada pelos dois autores do artigo. cussões na Internet, em que as pessoas divulgam seus roteiros, discutem sobre o peso ideal da mochila, o calçado mais adequado, as novidades tecnológicas para caminhantes, etc. ${ }^{4}$ A caminhada deixou de ser experienciada como um evento pontual e isolado, sendo incorporada ao nosso cotidiano.

\section{PEREGRINAÇÕES, CAMINHO DE SANTIAGOE NOVAERANAS CAMINHADAS ECOLÓGICAS}

Embora o foco de interesse empírico deste trabalho não seja o de eventos de peregrinação, os deslocamentos analisados relacionam-se, dealgum modo, com tal fenômeno e com o próprio movimento turístico (Graburn, 1989; Steil, 1996). Do ponto de vista histórico, a formação do Ecocaminhantes deu-se, justamente, com o rompimento dos três sócios da empresa com outro grupo de caminhadas, a Associação dos Amigos do Caminho de Santiago (ACASARGS). ${ }^{5}$ Ademais, a referência ao Caminho de Santiago é constante nas falas e imagens acionadas pelos caminhantes quando descrevem suas experiências de espiritualidade nas paisagens da natureza. No verbete que escrevemos para o Dicionário Brasileiro de Teologia, já oferecemos algumas pistas dessa possível relação:

Na condição da pós-modernidade, as peregrinações têm adquirido um novo impulso que vem tanto da revalorização de tradições pré-cristãs (europeia, orientais e indígenas) quanto da emergência das religiões do self, que vão enfatizar a dimensão da experiência pessoal e a imanência do sagrado na paisagem e na natureza. Valores como o cuidado do corpo, a ecologia, o sujeito psicológico como referência primeira para a vivência da fé têm encontrado nas peregrinações uma estrutura e um modelo ritual para se expressarem (Steil, 2008, p.784).

${ }^{4}$ Recebia notícias e participava das discussões, especialmente em duas listas de e-mails sobre caminhadas: caminhantes-do-brasil@yahoogrupos.com.br e santiago@yahoogrupos.com.br.

5 Trata-se de uma organização sem fins lucrativos que visa a promover e conservar o Caminho de Santiago de Compostela em percursos de caminhadas que reproduzem, no interior do Rio Grande do Sul, as dificuldades e as distâncias diárias percorridas no Caminho espanhol. 
Na sua raiz etimológica, o termo "peregrinação" deriva do vocábulo latino peregrinus, que significa "o estrangeiro, aquele que vive alhures e que não pertence à sociedade autóctone estabelecida, ou seja, é aquele que percorreu um espaço e, nesse espaço, encontra o outro" (Dupront, 1987). Tal acepção aponta, portanto, para o encontro com "o outro" como indicativo de um duplo aspecto. Por um lado, esse encontro remete às dificuldades objetivas da jornada empreendia pelo peregrino que, ao percorrer lugares desconhecidos e enfrentar as adversidades do caminho, termina por imprimir, nessa viagem, características de uma jornada heróica. E, por outro, refere-se ao ato de transformação de si, alcançado por meio de um deslocamento do "eu" em busca do "Outro", constituindo um percurso interior, de cunho místico e ascético, a ser realizado por aquele que peregrina.

Nancy Frey, em Pilgrim Stories: on and off the road to Santiago (1998), mostra como a peregrinação se inicia num período anterior à ida efetiva do peregrino a Santiago. O movimento físico no Caminhoé antecipado por uma espécie de movimento interno que convoca o peregrino a refletir sobre si, colocar em xeque seus "apegos", obrigando-o a decidir, por exemplo, o que levará na mochila durante os longos dias de caminhada. Essa convocação ao "desapego" se apresenta aos sujeitos como um exercício nãohabitual, contrastivo com sua vida cotidiana. A utilização desse recurso, que coloca em relevo oposições como cotidiano e não-cotidiano, trabalho e não-trabalho, ordinário e extraoridinário, para analisar e descrever práticas turísticas - sejam elas religiosas ou não -, tem sido frequente entre os pesquisadores desses fenômenos (Smith, 1989; Graburn, 1989; Urry, 1996).

Embora o "desapego" e a "viagem ao interior de si" possam ser vistas como características marcantes das peregrinações cristãs, os sentidos que elas assumem, na experiência dos atuais peregrinos do Caminho de Santiago, apontam para as transformações pelas quais passa a religião na sociedade moderna. A permanência de certas características das peregrinações cristãs - uma jornada penitencial, que encontra seu ápice no encontro com uma divindade que habita o santuário - contrasta com a busca mística de si, como uma jornada de santificação que encontra seu ponto de chegada no reconhecimento de uma divindade que se manifesta no interior de cada peregrino.

\section{A FORMAÇÃO DO ECOCAMINHANTES}

Desde 1994, segundo dados da OMT (Organização Mundial do Turismo), ${ }^{6}$ o ecoturismo tem um crescimento constante de $20 \%$ ao ano em todo o mundo. Apesar de escassos, os indicadores sobre esse segmento do turismo no Brasil também apontam para um aumento no número de agências, operadoras e grupos especializados em oferecer atividades de turismo e de lazer em meio à natureza. Sob certo aspecto, esse aumento foi impulsionado, nos últimos quinze anos, pela criação de unidades de conservação ambiental ou mesmo pelas adaptações infraestruturais em algumas cidades que se tornaram conhecidos sítios de ecoturismo. ${ }^{7}$ Ademais, as atividades propostas se diversificaram e, assim, determinadas parcelas da população, como a terceira idade, que até então estavam fora do alcance desse mercado, tornaramse ecoturistas em potencial. Conforme a EMBRATUR (Empresa Brasileira de Turismo), ${ }^{8}$ as caminhadas na natureza passaram a ser uma das práticas mais procuradas do ramo, contribuindo para um salto na geração de recursos desse segmento, que passou de $\mathrm{R} \$ 2$,2 bilhões em 1994 para pouco mais de $\mathrm{R} \$ 15$ bilhões em 2007. ${ }^{9}$

No entanto, o aumento na procura por esse tipo de atividade, que impulsiona os investimentos no setor, acompanha a lógica de transformações históricas nas relações entre humanos e natureza que, repletas de disputas e confli-

${ }^{6}$ Fonte: www.unwto.org/index.php (consultado em 08/ 05/2009).

7 Apenas para citar alguns que buscaram atender às demandas do ecoturismo: Bauru (SP), Bonito (MT) e Três Coroas (RS).

${ }^{8}$ Fonte: www.turismo.gov.br/turismo/home.html (consultado em 08/05/2009)

Fonte: www.turismo.gov.br/ (consultado em 08/05/ 2009). 
tos, promoveram, especialmente a partir da década de 1970, a expansão de certo ideário ecológico (Carvalho, 2002; Thomas, 2010). Os movimentos alinhados com a contracultura foram importantes nesse processo de contestação das perspectivas que tomavam a natureza como manancial de recursos para uso humano e passaram a concebê-la como espaço privilegiado para a harmonização da vida cotidiana, contribuindo, assim, para a expansão de determinadas sensibilidades relacionadas ao meio ambiente. ${ }^{10}$

O grupo Ecocaminhantes consolidou-se como uma das principais empresas de trilhas ecológicas do Rio Grande do Sul, mantendo uma agenda de atividades com a média de duas caminhadas por mês. Os destinos e a duração dessas atividades são variados, podendo acontecer ao longo de um único dia, em cidades do entorno de Porto Alegre, durante um final de semana ou feriado, em localidades mais distantes da capital gaúcha, como São José dos Ausentes (RS), ou ainda, podem ser caminhadas com mais de uma semana de duração, em outros estados e países, tais como: Chapada Diamantina (BA), Deserto do Atacama (Chile), Aconcágua (Argentina) e diversos parques na África do Sul. Para cada uma dessas atividades, constituem-se grupos com cerca trinta pessoas, sendo a maioria formada por mulheres com ensino superior, idade entre trinta e cinquenta anos, solteiras e residentes em grandes cidades. ${ }^{11}$ Fundada e administrada por três amigos que também

${ }^{10}$ A expansão de determinado ideário ecológico, a partir da segunda metade do século XX, esteve atrelada a um conjunto de movimentos contraculturais, que reconheceram nas questões ambientais uma via de acesso às críticas antimodernas por eles produzidas. Na esteira de alguns analistas do campo ambiental (Ferry, 1994; Carvalho 2002, 2009), pode-se situar o romantismo como uma importante fonte de produção da sensibilidade ecológica, bem como de um tipo de engajamento político por ela promovida. Conforme sugerem tais autores, a recusa às normatizações do fazer político, a valorização do self, da autoconscientização como ação transformadora e da politização do cotidiano individual são alguns dos elementos que caracterizam esse legado romântico na postura política ecológica. Essa perspectiva histórica, que situa o romantismo como balizador da emergência de determinada postura ecológica, pode ser tencionada a partir de textos que pontuam o projeto normatizador com raízes iluministas, que deram visibilidade às questões ambientais (Baubéro, 2001; Ribeiro 1992)

11 Esses dados foram fornecidos pela empresa Ecocaminhantes e estão publicados em Manieri (2008). são praticantes de caminhadas, a Ecocaminhantes presta um serviço profissionalizado, em que o contato dos clientes com a empresa é feito apenas virtualmente - desde a inscrição para participação nas caminhadas até os trâmites bancários - por meio de um website. ${ }^{12}$

Ao constituir-se como uma empresa de ecoturismo, a Ecocaminhantes passou a operar em uma faixa de preço que varia entre duzentos e cinquenta e trezentos e cinquenta reais para uma caminhada de um final de semana. Ainda que os destinos sejam variados, essas atividades podem ser descritas como de médias distâncias, ${ }^{13}$ percorridas em trilhas com mata fechada ou em extensos descampados, como os campos localizados na serra gaúcha e regiões litorâneas pouco habitadas. Esses grupos não passam de trinta pessoas e são sempre orientados por guias que os auxiliam ao longo do trajeto.

No que diz respeito à formação da Ecocaminhantes, ela se deu, justamente, a partir da discordância com alguns membros da ACASARGS com relação, por exemplo, aos roteiros de caminhadas, ao caráter turístico e ao enfoque religioso de suas atividades. A partir de então, três participantes da ACASARGS começaram a organizar suas próprias caminhadas, deixando de privilegiar estradas rurais parecidas com o Caminho de Santiago e passando a ter, como foco, trilhas na natureza. Nesse sentido, pensar a própria constituição da Ecocaminhantes pode fornecer uma chave interpretativa para não somente situar a dimensão religiosa do campo ecológico, como também para compreender as próprias transformações do campo religioso em direção a um movimento que aponta para a natureza como lugar do sagrado.

Assim, se, por um lado, a ACASARGS constitui-se como um grupo de caminhadas de orientação, a priori, religiosa, na qual o Caminho de Santiago de Compostela é uma das principais referências para seus integrantes, por outro, a Ecocaminhantes apresenta-se como um grupo que realiza trilhas

${ }^{12}$ www.ecocaminhantes.com.br

${ }^{13}$ As caminhadas têm em média 10 a $15 \mathrm{~km}$. 
ecológicas, pontuando, entre os objetivos de suas atividades:

\begin{abstract}
Organizar e promover caminhadas que permitam a integração entre os caminhantes e o meio ambiente; buscar percursos variados, onde o contato com a natureza esteja presente; incentivar e conscientizar sobre a importância de nosso ecossistema, despertando, assim, uma consciência ecológica. ${ }^{14}$
\end{abstract}

Ao narrar os motivos que levaram Daniel, um dos fundadores da Ecocaminhantes e antigo responsável pela elaboração dos roteiros de caminhadas da ACASARGS, a deixar o grupo de peregrinos, Ana, também sócia da Ecocaminhantes, aponta:

Ele [Daniel] queria oferecer mais para as pessoas. Por exemplo, aquela coisa de a gente ir atrás de patrocínio, de poder dar lanche, de oferecer coisas melhores, de não pegar um ônibus comum da prefeitura, de dar um ônibus mais legal, de comer num lugar melhor. Ele queria outro público e poder fazer trilha que o pessoal da Associação não faz... Eles fazem caminho em estradinha rural. Sei lá, longos, mas fáceis. (Ana)

A fala de Ana nos auxilia a depreender dois elementos importantes que consolidam alguns dos principais aspectos das experiências que estão em jogo nas caminhadas: o perfil de quem caminha e a paisagem em meio da qual se caminha.

\section{QUEM SÃO OS ECOCAMINHANTES?}

Embora diversas, as principais motivações que levaram os caminhantes a iniciarem a prática de caminhadas estão, na maioria das vezes, relacionadas com alguma ruptura, com alguma transformação na vida desses sujeitos. A caminhada aparece, nesses casos, como uma espécie de demarcador dessas mudanças. Vinícius, um advogado paulista de 39 anos, que vem a Porto Alegre (RS) todos os meses para caminhar com a Ecocaminhantes, afirma: ${ }^{14}$ Fonte: www.ecocaminhantes.com.br (consultado em
28/10/2009).
Quando era mais novo, eu caminhava, mas aí, por causa de rumos que a vida tomou, tive que parar. Agora faz três anos que me separei e tive um grave problema de saúde e então fiz uma reorientação de minha vida e a primeira coisa que fiz foi voltar a caminhar. (Vinícius)

Gilberto, outro ecocaminhante, conta que começou a caminhar depois de uma mudança em sua vida profissional e de uma separação conturbada:

Eu tinha uma empresa familiar, um hotel. Era um hotel médio, tinha 70 apartamentos, mas a gente ficava muito ligado e eu acho que foi no mês seguinte que terminou o hotel que eu pensei assim: eu quero me dar um presente, quero me dar uma coisa prazerosa. Eu não gosto do verão, quero ir pra um lugar frio. E ai alguém comentou: tu não queres ir para a Patagônia caminhar? Como também tinha acabado de me separar, decidi ir, pra mudar de vez. (Gilberto)

Juliana, uma professora de inglês aposentada, já fez o Caminho de Santiago duas vezes, além de ter sido hospitaleira ${ }^{15}$ em um albergue em Nájera, na Espanha. Ela também participou de um curso internacional sobre o Caminho na Universidade de Santiago de Compostela, é membro do conselho fiscal da ACASARGS e também participante da Ecocaminhantes. Em entrevista, conta que começou a caminhar após uma depressão psíquica.

Eu tive uma vez um problema de depressão e acho que, com isso, eu comecei a me antenar com essa coisa de caminhada, mais contato com a natureza e viver uma vida mais saudável. (Juliana)

Se, ao que parece, o início da caminhada dáse, para alguns, a partir de momentos de transformação de determinados estados, a confirmação dessa mudança-narram os próprios caminhantes-ocorre por meio da manutenção da prática da caminhada. "Caminho porque gosto, agora faz parte de mim e me lembra quem sou”, diz Vinícius. É assim que a prática da caminhada torna-se uma constante na vida desses sujeitos e deixa de estar restrita apenas às atividades promovidas por empresas de ecoturismo e associações de peregrinos, passando a

\footnotetext{
${ }^{15}$ Hospitaleiros são voluntários que trabalham nos albergues espalhados ao longo do Caminho de Santiago, recepcionando e acomodando os peregrinos que chegam.
} 
ser planejada por pequenos grupos que se formam a fim de realizar caminhadas pelo interior do Estado ou mesmo grandes atividades para o exterior. As falas de Gilberto, participante da Ecocaminhantes há quatro anos, e de Juliana, participante da ACASARGS e da Ecocaminhantes, nos dão a dimensão de algumas dessas caminhadas:

Então, daí começou a aparecer muitos passeios tipo esses da Ecocaminhantes de final de semana e, normalmente, coisas no interior do estado. E foi muito legal. Eu acho que a maioria desses passeios eu já fiz. Aquilo ali vai numa progressão [...]. No ano passado, por exemplo, a gente foi pra Tanzânia, fomos subir o Kilimanjaro, mas aí a gente começou a fazer as coisas por conta, porque fica muito mais barato [...]. A gente fazia assim: um procura passagem, outro roteiro... (Gilberto)

A Ecocaminhantes, para um dia só, eu acho que eles estão ficando caros. E eu tenho um grupo de amigos que a gente se reúne e faz caminhadas em Morro Reuter, numa caminhada da prefeitura de lá que tu pagas a alimentação e o resto é de graça, pagas uma taxinha para uma camiseta, uma coisa assim. Quer dizer, tu gastas trinta reais e ficas dois dias caminhando. Convives com um monte de gente. E também tem uma turma de Taquara que estão sempre organizando caminhadas e são pessoas muito queridas, eu caminhei com eles em Ivoti. Então é assim, junta o grupo e tu passas um fim de semana legal e barato. A gente começa a formar os nossos próprios grupos de caminhadas por afinidades. (Juliana)

\section{A CONSTITUIÇÃO DE CIRCUITOS DE CAMI- NHADAS}

Tanto entre os peregrinos quanto entre os ecocaminhantes, a prática de caminhadas é uma constante e não está restrita às atividades promovidas pelos respectivos grupos. Ao que parece, há um circuito de atividades no qual os caminhantes estão inseridos. No entanto, ainda que seja possível estabelecer distinções entre essas práticas e seus praticantes, o que nos interessa não são tanto as diferenças entre elas, mas sim o que permite a formação desse conjunto. Isto é, aquilo que amálgama essas atividades e que possibilita aos sujeitos em questão pertencerem, com aparente facilidade, a múltiplos grupos. Seguir os caminhantes nas suas narrativas acerca dos grupos com os quais interagiram para chegar seja à Ecocaminhantes, seja à ACASARGS, oferece-nos algumas pistas sobre os contornos desse circuito (Toniol; Steil, 2010).

Gilberto narra o início de sua prática de caminhadas a partir do contato com outra empresa de caminhadas ecológicas, chamada Rota Alternativa, ${ }^{16}$ com a qual fez sua primeira caminhada na Patagônia.

Acho que a Rota foi precursora da Ecocaminhantes [...]. E aí eu comecei justamente no programa top deles [referindo-se à Patagônia]. Os proprietários são o Nelson e a esposa dele. Eu também era cliente deles, mas agora viramos amigos, agora a gente faz passeios "extra Rota”, faz passeios por conta. A gente até está indo no mês que vem para o Vale do Pati [...]. Daí eu acabei conhecendo um pessoal que já tinha caminhado com a Eco e então fui caminhar com eles também. (Gilberto)

Ana fez sua primeira caminhada com a ACASARGS, a partir do convite de uma amiga, mas reconstrói essa trajetória apontando uma espécie de predisposição hereditária para as aventuras.

Primeiro, o que eu posso dizer é que eu não tinha o hábito da caminhada. Nunca tive, aliás, eu sempre tive um hábito, uma vida meio sedentária. Ginástica sempre fiz por obrigação, por saúde, eu tinha que fazer, para fazer alguma coisa mas eu nunca tive essa coisa de ginástica em si. Gostava de esportes e tal, sempre gostei muito do mar, dessas atividades onde vai todo mundo. Sempre gostei de umas coisas meio diferentes e acho que isso é de família, tenho dois irmãos velejadores, um é montanhista. Então, todo mundo é meio ligado à natureza. Comecei sem querer a fazer caminhadas porque uma amiga minha namorava um rapaz que era o presidente, na época, da Associação do Caminho de Santiago de Compostela, muito amiga minha. E eles sempre organizavam as caminhadas e sempre me convidavam: vai, vai. Mas eu não tinha vontade, porque eu visualizava aquela coisa de caminho de Santiago, peregrinação, que não tinha nada a ver comigo: não vou, não vou, não vou. Daí um dia ela disse: vem me ajudar. Porque era uma caminhada que tinha muita gente, era em Torres e eu: tá, então vou pra te ajudar. Daí fui caminhar e lá eu conheci o Daniel. Já na primeira caminhada. (Ana)

Ao sugerir essa herança familiar como possibilidade explicativa de sua identificação com a prática de caminhadas na natureza, a fala de Ana adquire

${ }^{16}$ Atualmente, essa empresa promove apenas caminhadas internacionais. 
similitudes às narrativas de uma conversão religiosa, em que uma predisposição já manifesta nos irmãos iria, um dia, manifestar-se nela também.

Fábio, primeiro, tomou contato com o Anamastê. ${ }^{17}$ Após uma passagem por esse grupo, passou a frequentar as atividades da Biodança ${ }^{18} \mathrm{e}$, por meio de alguns amigos da Biodança, com quem planeja fazer o Caminho de Santiago em 2010, conheceu a Ecocaminhantes.

Faz seis meses que comecei a caminhar com os Eco e já fiz caminhadas lá no morro Reuter, depois fui pra Florianópolis, Malacara, Praia Grande, Lagoa do Peixe e passei o ano novo com eles no Aconcágua. Mas tudo começou com um amigo meu do teatro, na verdade, um grupo que colocava muitos exercícios de preparação de ator na coisa da bioenergética que eles tinham aprendido lá no Anamastê, aí eu fiquei curioso. Aí eu fui lá e fiz seis aulas, eu não fiz as duas últimas. Fiz um trabalho fortíssimo e decidi me poupar. O trabalho de bioenergética é um trabalho forte, que ativa emoções que tu não conheces. Depois, conheci o pessoal da Biodança e aí fiz muitos trabalhos com eles. Neste ano, agora, vou para a Noruega e ano que vem para Santiago. É que o pessoal lá da Biodança tem um lado de espiritualidade forte, na coisa do desapego. Eu acho que essa coisa das caminhadas tem um lance inconsciente do desapego. $\mathrm{O}$ fato de tu saires da tua rotina e teres desapego à rotina, ao conforto... Aí acho que pega a todos [esses grupos]. Mesmo aqueles que não sabem o que é espiritualidade. Acho que a questão do desapego está presente em todos [os grupos]. A Ecocaminhantes pode ter uma intenção pedagógica na parte da ecologia. Eles explicam algumas coisas sobre ecoturismo. Eles fizeram uma formação de ecoturismo... Então ali acho que há uma intenção pedagógica, mas pedagogia para relações humanas ou terapia não é intenção deles. Mas, no final todos os grupos acabam sendo da mesma linha. Todos esses trabalhos procuram uma integração do homem com a natureza, uma parte menos artificial. (Fábio)

${ }^{17}$ Anamastê é uma prática de terapia alternativa que passou a se difundir com mais vigor a partir dos anos 2000 "A proposta é a de alcançar, por meio de exercícios físicos, a saúde plena do espírito". (Disponível em: www.anamastê.com.br. Acesso em: 28 jun. 2009)

${ }^{18} \mathrm{O}$ primeiro centro de formação em Biodança no Brasil a define do seguinte modo: "Biodança, a dança da vida, é um sistema de autoconhecimento, de integração, renovação orgânica e crescimento pessoal. Através do afeto por si mesmo, pelas pessoas, pela vida - os exercícios da Biodança, mediados pela música e pelo movimento, possibilitam o reforço da identidade: ser aquilo que se é, fazer o que se sonha, ter coragem para desenvolver os próprios potenciais." (Disponível em: www.biodanzabrasil.com.br) Acesso em: 28 jun. 2009)
A primeira grande caminhada de Vinícius foi "Passos de Anchieta". ${ }^{19}$ Nessa peregrinação, conheceu alguns gaúchos que já haviam feito caminhadas com a Ecocaminhantes:

Caminhei no Passos de Anchieta e um pessoal me comentou sobre os Eco. Agora todo mês venho para cá caminhar. Sair na sexta-feira do escritório em São Paulo e dizer que vai fazer trilhas no Rio grande do Sul tem seu charme. (Vinícius)

Juliana começou a caminhar com a Ecocaminhantes por meio da indicação de uma sobrinha que já conhecia o grupo. Após fazer algumas caminhadas, começou também a frequentar a Biodança, com quem foi para o Caminho de Santiago pela primeira vez. Após seu retorno de Santiago, entrou em contato com a ACASARGS.

Eu fazia Biodança com uma facilitadora muito legal, mas aí ela foi fazer uns cursos na Índia e acabou ficando por lá, se estabeleceu na Espanha e agora está em Ibiza. Continuei na Biodança, e os facilitadores novos fizeram um projeto de aliar exercícios da Biodança com o Caminho de Santiago, foi aí que fui pela primeira vez. Mas, eu já caminhava com os Eco antes disso. (Juliana)

Parece evidente, ao se avaliar os grupos pelos quais passaram os caminhantes até chegar à Ecocaminhantes ou à ACASARGS, a existência de um trânsito livre, sem muitos constrangimentos, que permite a esses sujeitos começar, parar ou permanecer participando das atividades de diversos grupos inadvertidamente. Exemplo disso é a participação simultânea de Juliana na Ecocaminhantes e na ACASARGS, ou, ainda, o contraste entre o caso de Fábio e Juliana, em que o primeiro chegou à Ecocaminhantes por meio de amigos da Biodança, e a segunda que somente após participar de caminhadas com a Ecocaminhantes iniciou suas atividades na Biodança. Mas, afinal, o que permite essa mobilidade entre grupos? Quais são os contornos desse circuito? O que há de solo comum entre essas práticas?

${ }^{19}$ O caminho "Os Passos de Anchieta" reconstitui o trajeto percorrido habitualmente pelo Padre Anchieta no final do século XVI, no litoral do Espírito Santo. A rota estendese por 105 quilômetros, margeando o litoral desde Vitória até a cidade de Anchieta, onde se encontra a Matriz erguida pelo padre e que foi a sua última residência. 
Ao investigar como se dá a conformação de um circuito neoesotérico, que agrega práticas distintas de xamanismo urbano na cidade de São Paulo, Magnani $(1999,1999 b)$ afirma que um dos elementos que possibilita esse fenômeno é:

... a intensa movimentação entre xamãs nacionais e internacionais, seus auxiliares, contatos, clientes, donos de espaços neo-esôs e de sítios que sediam as vivências. Assim é formada a malha ao longo da qual floresce esta particular modalidade de xamanismo, inventada a partir de elementos descritos em algumas obras consideradas clássicas, de ritos e crenças atribuídos a povos que ainda mantêm suas tradições e do multifacetado acervo mantido e continuamente realimentado pelo circuito neo-esô (1999, p. 133).

Para Magnani (1999, 1999b), outro elemento que dá forma a esse circuito de práticas distintas de xamanismo urbano é a construção de certa continuidade no discurso dos grupos, instituições e "facilitadores" que privilegiam noções como a de comunidade, de indivíduo e de totalidade. A articulação desses três polos, ainda que com variações, parece fornecer uma matriz que demarca alguns limites desse conjunto de práticas.

De certo modo, a articulação desses elementos - comunidade, indivíduo e totalidade - atravessa algumas das práticas em questão. No entanto, isso se dá não como discurso norteador, mas como questões em voga que compõem um panorama mais amplo de transformações em alguns aspectos da espiritualidade dos sujeitos.

Ao que parece, esse circuito percorrido pelos ecocaminhantes é composto por grupos que desenvolvem atividades sumariamente corporais. Na Biodança e no Anamastê, conforme explicaram Fábio e Juliana, pretende-se, por meio de exercícios físicos, alcançar determinados estados psíquicos, ativar sensações e experiências subjetivas a partir da exaustão. Já na Ecocaminhantes, na ACASARGS e na Passos de Anchieta, a atividade principal é a caminhada. O que sugerimos é que o corpo constitui-se como figura central nessas práticas. Trata-se, no entanto, mesmo nos casos citados de contato com o Caminho de Santiago e Passos de Anchieta, não de um corpo penitente em busca da redenção, mas de um corpo em direção ao aperfeiçoamento pessoal e ao cultivo de si.

Enquanto caminha na natureza, o caminhante não cultiva apenas seu bem-estar físico, mas seu corpo se constitui como um lugar em que se estabelece um fluxo constante entre as coisas relativas à alma, à mente e ao próprio corpo. Parece haver, no ideal de saúde desses sujeitos, uma espécie de interdependência entre as dimensões físicas e psíquicas, e o contato com a natureza torna-se, nesse contexto, um evento privilegiado na busca desse ideal. Ao compreender a prática de caminhada ecológica como uma terapia capaz de dar conta dessa concepção holística de corpo, o caminhante traz à tona o ambiente em que caminha - a natureza - como elemento-chave que compõe essa noção de bem estar.

A busca pelo aperfeiçoamento de si a partir do exercício físico da caminhada na natureza diz respeito também a uma tentativa por atingir o bemestar das coisas relativas à mente e à alma, que se estende para o ambiente. Perpassa essas práticas uma noção ampla de saúde que extrapola os próprios limites corpóreos dos sujeitos e incorpora os contornos físicos em que esses corpos estão situados, como condição para que se intaure uma experiência de bem-estar e saúde para tais sujeitos. Ou seja, não há possibilidade de os indivíduos alcançarem o ideal de saúde física ou mental em descontinuidade com a saúde e o cuidade do ambiente.

Essa relação, que torna intrínseca à experiência o ambiente em que se caminha, pode ser melhor compreendida quando refletida a partir da noção de paisagem explicitada por Tim Ingold, em seu livro The perception of the environment (2000). Sua perspectiva afasta-se de concepções que tomam esses espaços como objetos, panos de fundo, palcos, ou ainda como um cenário inerte no qual que se inscrevem as relações sociais. Para Ingold, a paisagem é a própria condição de ser no mundo, onde cultura, natureza e sujeito estão entrelaçados. A paisagem é concebida não como elemento externo às relações, mas ela própria constitui e é constituída pelas relações daqueles que a habitam. Nas palavras do autor: 
... nossa percepção do ambiente como um todo não provém de uma ascensão, de uma perspectiva panóptica e global, mas surge na passagem de um lugar para outro, e em histórias de movimento e de horizontes variáveis ao longo do caminho. (Ingold, 2005, p.93.)

Assim, é na medida em que estabelecemos relações, constituímos histórias, e percorremos a paisagem que ela toma forma. Apreender o que significa a experiência da caminhada para os caminhantes envolve, portanto, um esforço que compreende a maneira como esses sujeitos se relacionam com a paisagem em que caminham. Buscamos, assim, entender a paisagem não mais como algo externo à cultura, mas como constitutiva das dinâmicas sociais e temporais daqueles que a habitam, bem como, ela mesma, constituída pela rede de relações entre humanos e não-humanos que se encontram engajados nela.

Ao justificar sua falta de interesse em fazer o Caminho de Santiago, Gilberto afirma: "Parece que a paisagem lá não é o bicho, e nosso grupo valoriza muito a paisagem". Ao saírem da ACASARGS, os fundadores da Ecocaminhantes parecem ter deslocado a preocupação com elaborar roteiros que remetam ao Caminho de Santiago, ${ }^{20}$ para priorizar destinos que coloquem os sujeitos em contato direto com certo tipo de paisagem ecológica, como é apresentado em seus objetivos. ${ }^{21}$

O que sugerimos, enfim, é que há uma

${ }^{20}$ As caminhadas promovidas pela ACASARGS consistem na realização de trajetos que reproduzem, em alguma medida, na paisagem, a dificuldade e as distâncias que o peregrino enfrentará diariamente enquanto estiver percorrendo os quase 800 quilômetros do Caminho espanhol. Os trajetos são sinalizados com setas amarelas, como as existentes no Caminho de Santiago, as quais auxiliam o peregrino a encontrar sozinho a rota correta que deve seguir. A colocação desses sinais é justificada pelos membros da diretoria do grupo como tentativa de tornar aquela caminhada o mais parecida possível com o Caminho.

${ }^{21}$ Conforme o website, os objetivos da Ecocaminhantes são: organizar e promover caminhadas que permitam a integração entre os caminhantes e o meio ambiente; buscar percursos variados, onde o contato com a natureza esteja presente; incentivar e conscientizar sobre a importância de nosso ecossistema, despertando, assim, uma consciência ecológica; incentivar e conscientizar a prática da atividade física como manutenção da saúde mental e física; permitir a participação de todos os caminhantes, independente da preparação física, da idade e do ritmo de caminhada. ência dos sujeitos para certo ideário ecológico que só se torna eficaz porque tais práticas se efetuam numa paisagem que remete a uma concepção de natureza associada a uma ruptura com o cotidiano, vivido no meio urbano. Assim, não é somente o fato de estar ambientada numa paisagem bucólica ou rural que faz da caminhada uma prática ecológica, mas a própria noção de natureza, que inclui humanos e não-humanos numa totalidade e numa simetria relacional, o que a torna um evento capaz de se disseminar, de forma crescente, em muitas partes do país e do planeta.

Ana, uma das fundadoras da Ecocaminhantes, Fábio, também frequentador da Ecocaminhantes, e Juliana, que caminha tanto com a Ecocaminhantes como com a ACASARGS, relatam a relação entre a caminhada, a paisagem e a percepção:

É super importante na caminhada ter a paisagem; acho que é um momento que todo mundo para, olha e relaxa. O pessoal fica curtindo, é necessário. Faz parte, assim, para sair um pouco da vida da cidade. Por que caminhar no meio do mato ou numa estradinha? Eu acho que tem que haver um atrativo... Como paisagens diferentes sempre: mar, serra, cânion. Os cânions, por exemplo, a caminhada em si é uma caminhada de campo o tempo inteiro, mas o que é legal é caminhar e, no final, tu teres a paisagem: uma vista maravilhosa. (Ana)

Nossa sociedade está muito acostumada ao raciocínio, sempre olhamos pela lógica, e isso serve pra algumas coisas e outras não. Então, a gente tem que treinar a percepção direta do mundo. Às vezes, a gente está acostumada com uma rotina só, e nossa forma de perceber o mundo fica viciada. Então, a percepção é o carro chefe da caminhada. (Fábio)

$\mathrm{Eu}$, sinceramente, não gosto de repetir paisagem, não gosto de fazer circuitos, de caminhar em círculos. Com os Ecocaminhantes, por exemplo, já fui duas vezes para Fazenda Potrerinhos. Lá é muito lindo, muito legal. Mas, quando começa a repetir, não vou mais. (Juliana)

Mesmo que essas posições possam marcar algumas descontinuidades entre as características e perfis dos sujeitos que participam dos diferentes grupos de caminhada apresentados, o que nos interessa aqui, sobretudo, são as continuidades, as possibilidades de sobreposições das experiências. Ao sugerir interfaces entre as di- 
mensões ecológicas e religiosas, estamos apostando não nas transformações, mas, justamente, na permanência de determinadas sensibilidades em jogo. Trata-se de evidenciar, na constituição de grupos identificados com práticas de turismo ecológico, como a Ecocaminhantes, trocas, disputas, tensões que envolvem outros universos de sentido, como o Caminho de Santiago de Compostela. E, assim, chamar a atençao para a porosidade entre o ecológico e o religioso que aparece no contexto etnográfico que vimos acompanhando, experiencialmente imbricados.

\section{"VAMOS CAIR NA TRILHA": a experiência das caminhadas ecológicas}

Diante de uma oferta bastante ampla de locais em que se pode realizar uma caminhada, os idealizadores da Ecocaminhantes procuram propor roteiros que convirjam para seus próprios interesses.

... [o roteiro] é da nossa vontade, é o que a gente tem vontade de fazer. Porque é bem isso, como [a administração] da Ecocaminhantes é uma atividade que a gente tem que juntar com o nosso tempo livre de férias, então tem que ser uma coisa que a gente está com vontade de fazer também. Nas minhas férias, eu quero ir pra Patagônia. Então, tentamos montar, organizar um passeio e juntar as duas coisas. Para o Aconcágua, eu e o Daniel fomos no ano passado de férias e a gente falou: temos que trazer o pessoal pra cá. Então, sempre que a gente gosta de ir para um lugar, a gente tem vontade de levar todo mundo... E engraçado isso. Assim, num final de semana, a gente sai para passear... Bah, aqui era legal de trazer o grupo, então a gente está sempre tentando enxergar esse tipo de coisa. (Ana)

A maior parte desses destinos se concentra em trilhas na natureza. No entanto, apesar de predominantes, essas trilhas não são os únicos tipos de paisagem em que se realizam as caminhadas. Como transparece nas falas registradas acima, essa escolha está também relacionada com a "não-monotonia da paisagem".

Nossas praias [as do Rio Grande do Sul], por exemplo, é aquela reta interminável, com super vento que não dá trégua, e caminhar ali não é uma coisa agradável e acho que tem que juntar um pouco de paisagem, um pouco de tudo. [...] Por exemplo, nesse final de semana, a gente vai para Florianópolis, que é caminhada de praia, mas não é como aqui no Sul, que é uma reta só. Lá tem costão, sobe morro, desce morro, um pouquinho de praia plana, aí passa nas dunas... Então, é um pouco isso que a gente gosta de fazer, mesclar o tipo de paisagem. (Gilberto)

O tipo de paisagem em que se caminha bem como o fato de sempre haver novos roteiros são características apontadas pelos participantes como algumas das principais razões pelas quais a Ecocaminhantes se tornou um dos grupos com maior visibilidade na promoção desse tipo de prática no estado. A periodicidade dos passeios e a existência de uma loja virtual, na qual se pode, além de escolher a caminhada, efetuar seu pagamento, também possibilitam que a empresa tenha clientes espalhados pelo país.

\section{COMPRANDO UMA ECOCAMINHADA: o grupo e seus atores}

A empresa Ecocaminhantes não tem uma sede física, mas sim o domínio de um espaço na Internet, no qual divulga e comercializa caminhadas. Nessa página, encontram-se a agenda de atividades do grupo, fotografias dos passeios já realizados e algumas seções especiais que dão destaque a destinos como Patagônia, Chapada Diamantina, Aconcágua e África do Sul. Há ainda uma seção dedicada ao programa Trilha Limpa, que, segundo seus idealizadores, ao incentivar os caminhantes a recolherem o lixo que encontram pela trilha, endossa o principal objetivo da empresa: o de propiciar, por meio de caminhadas na natureza, "o desenvolvimento da atividade física e da consciência ecológica”. ${ }^{22}$

Cada passeio a ser realizado é apresentado no site com informações sobre a programação geral da atividade e uma classificação da caminhada segundo seu nível de dificuldade. Se-

${ }^{22}$ Fonte: www.ecocaminhantes.com.br (Acesso em: 01 dez. 2009). 
gue-se uma descrição dos trajetos a serem percorridos. A trilha do Rio do Boi (SC), por exemplo, classificada com um grau de dificuldade "pesado/ difícil”, é assim descrita na página do Ecocaminhantes:

Trilha do Rio do Boi: a caminhada ocorre no interior do cânion Itaimbezinho, sendo seu início em trilha por mata nativa, e, após, caminhada pelas pedras, no leito do rio do boi, com diversas travessias no mesmo rio, com direito a parada para banho nas piscinas e nas cachoeiras. Caminhada de aproximadamente $7 \mathrm{~h}$ e dificuldade alta. ${ }^{23}$

Além da obtenção de informações pelo site, os caminhantes também podem se atualizar sobre as atividades do grupo por meio de informativos via e-mail. A demanda pelos passeios é crescente, e muitas caminhadas têm o número de vagas esgotado em menos de uma semana após sua divulgação. Segundo Ana, mais de mil pessoas estão cadastradas no mailing da empresa, das quais cerca de seiscentas já participaram de alguma das caminhadas promovidas. Embora sejam números expressivos, a Ecocaminhantes não se utiliza de veículos de propaganda além do próprio site.

A gente não faz propaganda. Então, ou vai ser por indicação de alguém que a pessoa fica sabendo de nós. Já aconteceu de gente que está procurando alguma coisa para fazer, digitou no Google "caminhada" e aí apareceu "Ecocaminhantes". Com um ou outro já aconteceu isso, mas normalmente é por indicação. Nem é no site que se entra primeiro. Muitos ligam direto, sem entrar no site. Normalmente é por indicação e nunca por propaganda. Até porque, como a gente não tinha a ideia de transformar isso num negócio, a gente nunca quis fazer propaganda, porque aí tu tem que estar preparado para receber uma demanda grande. (Ana)

Ao que parece, a indicação configura-se como elemento central do ingresso nesse tipo de atividade. Trata-se, portanto, não somente de uma prática na qual os sujeitos se engajam por interesses pessoais, mas também por estarem envolvidos em determinadas redes de sociabilidade que proporcionam essa entrada. A caminhada, nesse sentido, constitui-se num evento de socia-

${ }^{23}$ Fonte: www.ecocaminhantes.com.br (Acesso em: 01 dez. 2009). bilidade não apenas para aqueles que já se conhecem, mas também para aqueles que pretendem estabelecer novos contatos:

Tem duas coisas que são boas: a caminhada em si, que independe do lugar, e também tem um tipo de gente que faz essas caminhadas que é o tipo de pessoas com quem eu gosto de estar, que eu me sinto bem. Não importa se é com a Ecocaminhantes, com a Rota. Nem precisas saber se tem algum amigo teu. Tu vais encontrar alguém, às vezes eles mudam de nome, mas no final são todos iguais. (Gilberto)

Diversos trabalhos (Amirou, 1995; Siqueira, 2006; Steil, 2003), que tiveram como foco de interesse atividades turísticas, sugerem a existência, nesses contextos, da emergência da modalidade de inter-relacionamento que Turner denominou de communitas. É essa experiência da communitas, marcada pela facilidade em estabelecer vínculos, pela camaradagem e pelo espírito de igualitarismo, que permite, por exemplo, a Gilberto afirmar que os sujeitos apenas mudam de nome, "mas no final são todos iguais". Para Turner, todos esses aspectos são característicos de momentos não-estruturados, nos quais as marcas da diferenciação social, as posições, enfim, tudo aquilo que classifica os sujeitos em uma determinada estrutura desaparece, permitindo o surgimento de um modelo de relações nãopautado pelo que é normativo e estruturado, mas sim pelo não-estrutural (Turner, 2008).

Contudo, um dos limites desse tipo de leitura é que, ao se creditar à communitas relações de tipo não-estrutural, corre-se o risco de não perceber que, embora possam parecer fluidas e indiferenciadas, essas relações se originam da convergência das posições estruturais ocupadas por tais sujeitos. Isto é, o modelo de análise processual turneriano, que concebe a dinâmica social como fruto da contínua tensão entre estrutura e communitas, quando verificado empiricamente, parece um tanto rígido. Nessa mesma linha, argumentamos que: "A estrutura e a communitas se conjugam dentro do próprio evento, desconstruindo a ideia da contradição entre o espaço da estrutura e o da communitas enquanto entidades separadas" (Steil, 2003, p. 34) 
Outra característica marcante das caminhadas é a predominância de mulheres em relação aos homens. ${ }^{24}$ Algumas atividades chegam a ser realizadas com a presença, exclusivamente, feminina.

Eu acho que os homens pensam que caminhada não é para homem. Homem, se convidar para um raffting ou rapel, eles vão, mas, se é pra uma caminhada... Isso é totalmente preconceito masculino. Eles pensam que não é coisa que homem possa fazer: passar o fim de semana caminhando. Talvez, se a gente desse outro nome, aparecessem mais homens. As mulheres têm, nesse sentido, mais atitude. Quando estão sozinhas e querem fazer uma coisa, elas vão atrás, buscam, procuram e se juntam com outras para isso. Mas, homem sozinho, acho que é mais difícil de fazer isso. Se não é um amigo que convida, alguém que traz junto... Acho que dificlmente, por conta própria, ele olha um anuncio e diz: "vou caminhar”. Mas, é sempre muito mais mulher. (Ana)

A fala de Ana trazà tona dois focos explicativos para a pouca presença masculina nesses eventos. O primeiro deles se refere ao caráter da própria prática da caminhada, a qual parece não estar tão afeita às masculinidades quanto os chamados esportes de aventura. O segundo diz respeito à dificuldade, por parte dos homens, de se mobilizarem para participar dessas atividades. Tendo em vista que as caminhadas são encaradas por muitos como um promissor evento de sociabilidade, a ausência masculina desestimula a permanência de alguns sujeitos no grupo. Como ocorre no caso narrado por Gilberto, "a própria pessoa que me convidou para caminhar pela primeira vez parou de caminhar, porque disse: ali eu não arrumo nada. Até porque noventa por cento é mulher".

\section{A CAMINHO DA CAMINHADA}

A construção de um corpo caminhante não ocorre somente nas caminhadas. Esses corpos, na verdade, são forjados gradualmente, conforme os sujeitos se engajam na prática de caminhar e incorporam determinados sensos éticos,

${ }^{24}$ Segundo dados fornecidos pela empresa Ecocaminhantes e publicados em Manieri (2008), 76\% dos participantes das caminhadas são mulheres. ecológicos, religiosos. O engajamento informa ao caminhante as habilidades técnicas, os gestos e o saber-fazer valorizados nesses eventos. É necessário compreender, portanto, que o universo das caminhadas remodela os corpos, convertendo-se em um marcador temporal na vida desses sujeitos, transformando sua rotina e, possivelmente, alterando suas categorias de apreciação.

Tornar-se caminhante é apropriar-se de uma determinada corporeidade, de modos específicos de estar atento "a" e "com" o corpo, sem que, no entanto, haja distinção entre aquilo que é domínio do físico, do mental ou do espiritual. No corpo, tudo isso está conjugado, e a corporeidade refere-se, justamente, a tais arranjos.

Se, por um lado, a mediação da agência de turismo é importante e valorizada nas falas dos ecocaminhantes, por outro, ela também é questionada e pode se tornar dispensável, de modo que os seus participantes acabam valorizando as caminhadas organizadas e empreendidas por eles mesmos. Como relata Gilberto:

Aparecem muitas dessas viagens curtas [...]. Por exemplo, minha família tem apartamento em Gramado, então nós já fomos três vezes em Gramado caminhar. Meu irmão tem apartamento em Torres, aí nós fomos lá nos dias 12 e 13 de setembro, numa mistura de gente e inventamos uma caminhada. Estas caminhadas acabam não saindo tão caras, porque tem só que pagar passagem. O pessoal também gosta de cozinhar e aí fazemos a caminhada. Nós também fomos para Teutônia, uma das gurias mora lá. Em Caxias, também a gente foi para Caravagio, isso acaba saindo bem barato. E acho que tem opções... Fomos para Sertão Santana num dia desses também. O pessoal acaba saindo por conta, parece que dá uns estalos, o pessoal começa a se afastar das agências e fazer as coisas por conta. (Gilberto)

Como podemos perceber, essas iniciativas independentes das agências são formas de grupos de caminhantes, que possuem uma sociabilidade anterior estabelecida a partir de outras redes de relacionamento, se encontrarem. Mas essa sociabilidade pregressa pode aparecer no âmbito das próprias agências. Em algumas caminhadas, um grupo de cinco ou seis pessoas faz a inscrição no mesmo evento e se integra ao grupo maior. O senti- 
do coletivo da prática da caminhada informa aos caminhantes o modo pelo qual devem se mover, relacionar-se com a paisagem, enfim, sustentar determinada hexis corporal. Esse compar-tilhamento está relacionado com a construção de uma técnica do corpo específica que, conforme definiu Marcel Mauss (2003), é obra da razão prática coletiva e individual. Em parte, é a partir da incorporação dessas técnicas que o corpo do caminhante é forjado.

A relação entre a coletividade da prática e a incorporação das estruturas de sentido fomentadas por essas práticas constitui também questão central ao paradigma da corporeidade de Thomas Csordas. No entanto, se, para Mauss, essa coletividade é constituída por sujeitos que compartilham determinadas técnicas corporais, para Csordas, a coletividade se dá com o compartilhamento de corporeidades. Noutro paralelo possível, aquilo que, para as teorias cognitivistas, é a intersubjetividade, na proposta de Csordas configura-se como intercorporeidade. Isto é, trata-se da comunhão de determinados modos culturalmente elaborados de experienciar o mundo.

Nas caminhadas, os participantes do grupo trocam informações sobre os roteiros que devem e os que não devem ser feitos. Essa troca não apenas informa um elenco de destinos interessantes para os caminhantes como também ajuda a constituir, de algum modo, um sistema hierárquico de classificações desses roteiros. A partir de um conjunto heteróclito de elementos, tais como o contato com a natureza, a exoticidade e as dificuldades enfrentadas durante a viagem, os destinos turísticos são hierarquizados e posicionados como mais ou menos autênticos entre os caminhantes. Partilhar esses esquemas de classificação e posicionar-se como consumidor das caminhadas mais valorizadas é um elemento importante na demonstração do engajamento nessa prática.

Acho que isso mexe com a inveja, que o pessoal fala: bah, eu fui para...; bah, quero fazer esse aí também. Aí o outro: ah, mas eu fui para África. Eu acho que tem uma oferta, uma troca de informação... (Fábio)

Hoje a gente tem bastante contato com o pessoal que caminha. Aí, é um dando dica para o outro, e a gente fica cheio de coisas na cabeça e fica só anotando e, claro, conforme o tempo dá, a gente vai fazendo as coisas que as pessoas falaram e o que a gente realmente acha legal. A gente gosta de fazer coisas diferentes, sair do padrão. (Ana)

Eu acho que as coisas vão crescendo, que é um caminho natural. Tu começas com uma caminhadinha pequena, depois você vai indo, indo, e aí tu queres fazer mais, não sei se chega a ter um espírito de competição. Um fala: olha, eu fiz isso. Aí o outro fala: isso é melhor. Eu acho que tem uma coisa de consumo, por que não? Que diferencia até... Você conhece a pessoa e pensa: o cara já foi para tal lugar. Tem um grupo aqui que está fazendo a cordilheira branca, no Peru, e eles têm o objetivo de caminhar em todos os lugares do mundo e não repetir nenhuma caminhada. (Gilberto)

Se a troca de informações sobre roteiros é um aspecto importante da constituição de um caminhante, é na própria caminhada que esse aspecto fica mais evidente. Durante uma das saídas de campo que realizei - um passeio de três dias pelos Campos de Cima da Serra Gaúcha, no município de Cambará do Sul/RS - tomei a seguinte nota: ${ }^{25}$

Gilberto foi um dos últimos a chegar e, assim que colocou sua mala no bagageiro, entramos no ônibus e começamos a viagem para Cambará do Sul/RS. A ida é o momento de menor interação do grupo, mesmo tendo uma grande quantidade de pessoas que procuram esta atividade justamente para estabelecer amizades. Sentei-me com Gilberto e começamos a conversar sobre algumas trilhas que ele havia feito. Depois de algum tempo de viagem, Ana juntou-se a nós e nos apresentou Vinícius, que estava sentado no banco logo à nossa frente. Ana acabara de voltar de uma viagem de férias na África do Sul e narrou detalhadamente todas as trilhas que ela e Daniel fizeram nos parques daquele país. Gilberto não perdeu a oportunidade e passou a nos relatar as dificuldades que estava enfrentando na preparação de sua viagem ao Nepal, aonde iria, com um grupo, subir até o acampamento base do Everest. Vinícius, como que para apresentar sua relação de viagens, passou a nos descrever as principais caminhadas que já havia feito: “...o primeiro passeio que fiz foi logo depois que me separei. Chama Passos do Anchieta, são quatrocentos quilômetros entre o Espírito Santo e São Paulo. Aí peguei gosto pela coisa, vim pra cá fazer o Caminho das Missões e depois fiz duas coisas que sempre tive vontade, subir o pico da Bandeira e o da Neblina, bicho, foi rojão! Lá eu conheci duas pessoas que me convidaram para caminhar na

${ }^{25}$ Diário de campo de Rodrigo Toniol. 
Eslovênia, voltei de lá na semana passada. Caminhei em vários parques lá também.” [Nota de 15 de agosto de 2008]

Uma das ideias-chave que vimos desenvolvendo neste artigo é a de que há uma relação entre ocupar uma posição privilegiada num sistema hierárquico que classifica as caminhadas como mais ou menos autênticas e o grau de dificuldade que tal destino impõe ao caminhante. Isto é, quanto mais difíceis de serem acessados e concluídos, mais valorizados são os destinos. No entanto, se, por um lado, as dificuldades enfrentadas contribuem para a valorização de uma viagem, por outro, essas dificuldades devem estar circunscritas a um limite de tolerância que precisa ser respeitado.

Alguns que caminham com a gente curtem ir para hotéis tipo Casa da Montanha, que é considerado quase um resort, é um hotel padrão classe A. Eles são ligados à natureza, mas querem luxo, querem passar bem. Podem sofrer na caminhada, não tem problema em se sujar todo, se encher de lama, tomar banho de chuva, isso não importa, mas depois querem chegar a um lugar bom, confortável para poder tomar seu vinho e tal. (Ana)

O mais importante pra mim não é chegar, mas sim caminhar, com certeza. Assim, o objetivo não é ir lá, não! Uma das coisas que foram se reforçando com o tempo para mim foi isso. Eu não recomendaria a Tanzânia, por exemplo, nem para um inimigo, porque o final dela é muito, muito difícil, e quando tu chegas nesse ponto, a coisa fica desagradável, porque sai do controle, não tem essa de dizer: Eu subi o Kilimanjaro. Grande coisa, o objetivo é o caminhar, não a chegada. Mas para o pessoal é... Tanto assim que, no Everest, quando tu chegas no campo base e o pessoal está muito cansado, a 5600 metros, caminhando muito devagar e realmente não é o ponto mais bonito, você vai lá para dizer que chegou. O mais bonito não é lá, está atrás... Mas a maioria vai para dizer: eu cheguei. (Gilberto)

Tem uma coisa de provação também. A gente fez a caminhada no Aconcágua e estávamos liquidados, alguns passando mal e tal, mas é aquela coisa: "Passei pela dificuldade, pelo desconforto, mas agora eu vou pra Mendoça e quero a parte fácil.” Aí a gente foi em vinícolas, free shop, aí dá pra notar que ali teve o turismo como prêmio pela provação que passou. (Fábio)

Uma vez apresentado esse panorama geral da Ecocaminhantes e da prática da caminhada, pretendemos retomar a questão da corporeidade com que iniciamos este artigo. A experiência de caminhar que vimos acompanhando aponta para o delineamento de dois modos somáticos de atenção que, ao que parece, constituem o corpo do caminhante: a exaustão física e a relação estabelecida com a natureza.

\section{MODOS SOMÁTICOS DE ATENÇÃO E O PARADIGMA DA CORPOREIDADE: uma breve retomada}

O projeto teórico de Thomas Csordas é o de desenvolver a corporeidade com um paradigma para a antropologia. Esse modelo analítico concebe o corpo não como como a base existencial da cultura. O que está em jogo, na corporeidade, é compreender o corpo como a própria condição da existência humana e o solo da cultura. Amparado nas contribuições da Filosofia Fenomenológica de Merleau Ponty $(1971,2000)$ e da Teoria da Prática de Bourdieu (2008), Csordas compõe seu próprio arranjo teórico, tornando central, para sua análise, as experiências culturalmente padronizadas nos corpos dos sujeitos, onde reside o lócus da cultura. Assim, para refinar seu constructo teórico e tornar a corporeidade um procedimento metodológico, ele lança mão do conceito de modo somático de atenção, que remete à experiência cultural de estar no mundo atento "a" e "com" o corpo. "Estar atento a diz respeito à atenção dada ao estado do corpo no mundo, um modo de estar atento ao meio intersubjetivo que ocasiona aquela sensação. Estar atento com refere- se ao modo de engajar os sentidos numa determinada atenção." (Csordas, 2008, p.372).

Para Csordas, é justamente na variação dos modos de estar atento "a" e "com" o corpo, na corporificação das experiências eno compartilhamento dessas corporeidades, que se deve iniciar uma análise fenomenológica da cultura. "O que quero dizer é que as maneiras pelas quais damos atenção aos e com os nossos corpos, e mesmo a possibilidade de dar atenção, não são nem arbitrárias nem 
biologicamente determinadas, mas são culturalmente constituídas" (Csordas, 2008, p.374).

\section{A EXAUSTÃO DOS CORPOS DOS CAMI- NHANTES EA VALORIZAÇÃO DA EXPERIÊN- CIA DA CAMINHADA}

Partindo da premissa teórico-metodológica de que a experiência corpórea é o fundamento existencial da cultura e do sujeito (Csordas, 2008), buscamos colocar em foco a maneira pela qual alguns aspectos da prática das caminhadas são articuladas nos corpos dos caminhantes. Trata-se de tomar, como ponto inicial de análise, uma fenomenologia cultural das experiências corporeificadas pelos caminhantes para, desse modo, poder refletir sobre seus pertencimentos, suas sensações e os seus sentidos, postos em jogo na caminhada.

O modo somático de atenção que delinearemos nesta seção é o da "exaustão física" durante e após as caminhadas com a Ecocaminhantes. Como já foi apontado noutro momento, parece haver uma relação entre as dificuldades enfrentadas, sejam elas de acesso a um destino ou na conclusão de um trajeto com muitos obstáculos a serem ultrapassados, e a valorização do consumo do roteiro por parte dos caminhantes. Aqui, por sua vez, nos interessa atentar para as dificuldades físicas que a caminhada impõe aos sujeitos. Essas dificuldades podem ser expressas a partir de diversas experiências corpóreas. Dentre elas, podemos citar a dor.

No horizonte de uma visão cartesiana, onde prevalece uma "preeminência da mente sobre um corpo visto como inerte, passivo e estático" $(2008$, p. 370$)$, a exaustão e a dor seriam descritores de uma ordem cultural que se inscreve no corpo. Ao passo que, quando analisados sob o paradigma da corporeidade, tanto a dor quanto a exaustão tornam-se centrais em termos epistemlogicos e analíticos para que se possa compreender a experiência vivida pelos caminhantes e o solo cultural que sutenta a sua prática. Essa experiência, na medida em que é compartilhada por uma coletividade, conforma uma situação de intercorporeidade em que os caminhantes se veem engajados existencialmente.

A descrição da experiência da caminhada, para muitos dos caminhantes, tem como fio condutor os percalços, as dificuldades enfrentadas nas distâncias percorridas, os terrenos íngremes, as intempéries. A exaustão física é posta em relevo, e essa valorização das dificuldades contribui para tornar mais "autêntica" a experiência entre os sujeitos. Corporalmente, essa sensação é narrada por meio de modalidades sensoriais indeterminadas, que oscilam entre a expressão da sensação de um "corpo esgotado" e de uma "mente revitalizada". A elaboração de descrições ambivalentes, que ora tendem para expressões relativas ao corpo e ora para expressões relativas à mente ou alma, remete a um fluxo contínuo entre modalidades sensoriais capazes de estarem presentes nessas duas alçadas. Isto é, ao proporcionar descrições somáticas que se configuram a partir de um arranjo híbrido, que conecta sensações físicas e experiências da ordem da mente ou alma, as caminhadas tornam-se um contexto privilegiado para a análise que tem como uma de suas premissas básicas o colapso entre essas esferas.

A exaustão corporal parece ser somatizada pelos caminhantes como aspecto essencial para que a experiência da caminhada torne-se autêntica. Em um passeio com os ecocaminhantes na cidade de Mostardas (RS), perguntamos a Fábio se considerava aquela uma experiência turística:

Não, porque turismo, como eu vou te dizer?
Quando você faz turismo tudo está certinho, nada
dá errado, você não vive aquele lugar direito, é
como se você não estivesse ali, é como fazer sexo
com camisinha! Aqui na Eco vivo intensamente
a caminhada. Prova disso é que a gente fica exaus-
to, o corpo cansa e por isso não é turismo, aqui é
de verdade. (Fábio)

A fala de Fábio torna evidente que a experiência vivida como ecocaminhantes está distante do que pode ser experimentado como turismo, não apenas em termos conceituais, mas, sobretudo, corporais. Assim, se a ausência da dor e da 
exaustão - satisfação e lazer - caracterizam o turismo, a presença dessas sensações somáticas é a marca do engajamento corporal dos ecocaminhantes. Assim, a sensação de mergulho numa atividade em que a dor é intensa e o esgotamento físico profundo torna-se o divisor de águas entre o que esses sujeitos vivenciam como turistas e como ecocaminhantes.

A dor e a exaustão são, assim, vividas como uma espécie de via de acesso ao bem-estar produzido pela intensa atividade corporal - a caminhada que termina por constituir-se como "uma maneira de purificar a mente e a alma, um refúgio para recarregar as energias e um momento para desestressar" (Marina). Caminhar junto à natureza torna-se, desse modo, uma experiência corpórea que estabelece um fluxo e uma corrente contínua entre o físico e o mental, o material e o espiritual, o corpo individual e o seu contorno ambiental. Nesse sentido, dois depoimentos são ilustrativos desse colapso que se realiza na experiência aqui analisada.

Fiz uma reorientação de vida em que decidi mudar. Para deixar de ser obeso, podia fazer cirurgia de estômago, mas não ia estar saudável. Tem que se encontrar consigo mesmo pra ficar saudável. (Vinícius)

Através de exercício físico, você rompe com as couraças que se formam nos chacras das pessoas por causa da falta de meditação, concentração, bons fluidos, etc. Com as couraças quebradas, o sujeito alcança determinado estágio que é por todos almejado. Caminhar te coloca em certo estado mental interessante. (Fábio)

Ao lado da dor e da exaustão, que remetem à corporeidade como um modo específico de estar atento "a" e "com" o corpo, a experiência dos ecocaminhantes define-se também pela paisagem em que transcorre a caminhada. Como nos referimos anteriormente, assim como o corpo, a paisagem aparece aqui como um elemento ativo que atravessa e constitui as experiências daqueles que a percorrem nas caminhadas ecológicas. "É na natureza, e somente nela", afirma Marina, uma caminhante de 29 anos, "que podemos sentir o mundo de outro jeito, de um jeito em que a gente não está acostumada”. Essa relação especial com a paisagem poderia ser percebida, segundo os ecocaminhantes, pela constatação de que eles compartilhariam de uma sensibilidade que seria captada por meio da técnica fotográfica. Como aponta Fábio, “... tem um dado importante, acho que o pessoal todo se interessa muito por fotografia, pode ver que eles querem tirar foto na natureza porque é diferente de tudo, a imagem da natureza é diferente, e isso é uma coisa da percepção.” (Fábio).

Enfim, se a experiência da dor e da exaustão corporal aponta para uma espécie de interdependência entre as dimensões físicas e mentais ou espirituais, a referência à paisagem permite perceber que os corpos que estão em jogo não podem ser compreendidos como meros substratos biológicos, mas, ao contrário, são eles mesmos incorporados numa dimensão holística que os circunscreve. É justamente essa experiência de uma natureza revitalizante, capaz de gerar sensações que conectem corpo, mente ou alma e paisagem, que procuraremos apresentar, na próxima seção, como outro modo somático de atenção presente na intercorporeidade dos ecocaminhantes.

\section{A RELAÇÃO CAMINHANTE-NATUREZA COMO UM MODO SOMÁTICO DE ATENÇÃO}

O modo somático de atenção referido a partir de agora - o da relação caminhante-natureza - é articulado entre os ecocaminhantes em termos da potência dessa paisagem específica em produzir sensações ligadas a uma espécie de aperfeiçoamento de si, tais como "autoconhecimento", "mente e alma purificada" e "sensação de plenitude". A maior parte desses relatos está afinada com certo "espírito Nova Era", cuja relação com o sagrado se dá a partir do contato com uma natureza investida de forças místicas e energéticas, capazes de ser incorporadas pelos sujeitos.

Ao sugerir a existência de um modo somático que articule caminhante-natureza, queremos chamar a atençao do leitor para uma forma específica de sensação corpórea na qual algumas das experiências vividas na natureza são vivi- 
das como contatos com um transcendente. ${ }^{26}$ Essas experiências são geralmente descritas como: sensação de energia passando pelo corpo, purificação da mente, leveza do corpo, sensação de presença de boas energias, corpo revigorado, descarga de más energias acumuladas, relaxamento. Esse breve inventário de sensações, retirado dos nossos diários de campo, reitera a existência de um engajamento sensório específico que se concentra em três modalidades perceptivas: tato, visão e aquilo que chamaremos de cenestesia. ${ }^{27}$

As experiências táteis aparecem geralmente associadas às manifestações sentidas na forma de energias. Um movimento corporal característico dessa modalidade é a imposição de mãos sobre pedras e árvores, acompanhada pelo fechamento dos olhos. Por meio desse contato, afirma Mariana, uma caminhante de quarenta anos, "posso descarregar minhas energias ruins e receber as boas que a natureza tem para me oferecer”. Num outro trecho do diário de campo, registrado na caminhada à cidade de Caará (RS), na nascente do Rio dos Sinos, anotei: ${ }^{28}$

Chegamos à nascente e nos deparamos com uma cachoeira de cento e vinte metros de queda d'água. Sentei-me perto de Marina e perguntei como se sentia. Descreveu-me que a natureza tinha o potencial de "purificá-la", uma força que poderia sentir agir em seu corpo por muitos dias após aquela experiência. Enquanto conversava com Marina, observava Mariana, que se aproximou de uma grande pedra e abraçou-a vagarosamente permanecendo ali por alguns minutos.

Essa descrição aponta para dois efeitos possíveis, que são buscados no contato entre os corpos dos caminhantes e os elementos da nature-

${ }^{26}$ A ideia de transcendência utilizada nessa passagem, não se refere a uma Transcendência da Revelação, como a que pauta o cristianismo. Mas diz respeito a uma transcendência na imanênicia, em que a relação com o sagrado não se dá a partir da mediação da Igreja, mas sim num plano individual, imanente. (Ferry; Gauche, 2008)

${ }_{27}$ Agradecemos a Luiz Fernando Dias Duarte que, por ocasição da apresentação de uma versão inicial deste texto no $34^{\circ}$ Encontro da ANPOCS, sugeriu o uso desse termo. Trata-se, segundo o dicionário Houaiss (2001), de uma "designação genérica para as impressões sensoriais internas do organismo, que formam a base das sensações, p.ex., de estar com saúde, de estar relaxado etc., por oposição às impressões do mundo externo, percebidas por meio dos órgãos dos sentidos”

${ }^{8}$ Trecho do diário de Rodrigo Toniol.

za. No primeiro, o contato tátil e direto entre o corpo e a pedra permite ao caminhante incorporar as "boas energias" que esse elemento emana. No segundo, o contato visual com a paisagem busca a purificação e o rejuvenescimento dos corpos humanos. Essas experiências de contemplação da natureza podem harmonizar o estado corporal e espiritual de sujeitos em sua relação com uma paisagem que integra, numa totalidade, humanos e não-humanos. Ao descreverem essas sensações, os caminhantes recorrem com frequencia a um léxico concernente ao "idioma religioso", tais como "purificação", "plenitude” e "totalidade".

Ainda na caminhada até a nascente do Rio dos Sinos, questionei Mariana sobre possíveis motivações religiosas em sua participação naquela atividade:

Motivação religiosa não tenho nenhuma. A natureza é o lugar da espiritualidade, não é uma religião, porque não é rígida, não impede o sujeito de despertar suas próprias crenças. A natureza é viva, não tem dogmas. Você não acredita que aquela árvore ali está agora nos olhando? Aqui a gente é total, não está amarrado pela igreja. (Mariana)

Noutro momento, enquanto conversávamos sobre roteiros de viagens, Joana, uma professora universitária, relatou:

Olha, teve uma vez que me perdi com meu filho numa trilha em Fernando de Noronha e a gente caiu num lugar lindo. Demos sorte de ver o pôr do sol e vou te dizer que podia morrer naquele momento, estava num estado de plenitude. Não importa o que acontecesse, era como se não estivesse mais ali (Joana).

O que parece estar em jogo, nessas falas, são experiências do sagrado intimamente associadas à paisagem, em que a identidade religiosa é resolvida no plano da individualidade. A atenção do modo somático a que nos referimos está dirigida a essa paisagem natural que, experienciada por meio de sentidos como o tato e a visão, termina por promover um tipo de relação específica com o sagrado.

Uma última modalidade de experienciação a ser descrita é a que chamaremos de cenestesia, referindo-nos, sobretudo, à sensibilização corpo- 
ral dos sujeitos para que possam perceber o fluxo energético que os atravessa na sua relação com a natureza. Essa percepção é resultado de uma educação para a atenção que permite aos caminhantes conferirem agência a elementos como árvores, animais, lua, sol, pedras, que, por sua vez, passam a ser capazes de agir sobre a própria percepção dos sujeitos em relação a seus corpos.

Fábio, um ecocaminhante que chegou ao grupo por meio do teatro, narra sua trajetória religiosa:

Quando eu comecei no teatro eu era cético, ateu. Mas aí coisas foram acontecendo [...]. Por exemplo, tem uma coisa que a gente faz no teatro que vem da yoga, que é a saudação ao sol e, se tu imaginar que está saudando o sol mesmo, parece que dá um tônus diferente no corpo. Isso dá outra disposição pra gente, aí o cético começa a ver que tem coisas que não sabe explicar como acontecem e aí tu não sabe se aquilo é psicológico, imaginativo... Aí é melhor tu aceitar assim, se tu aceitar assim o resultado é melhor. (Fábio)

O relato de Fábio atribui ao contato com a natureza, investida da capacidade de emanar "boas energias", a aquisição de um "tônus diferente" em seu corpo. A possibilidade dessa aquisição, no entanto, está diretamente relacionada com a constituição de uma forma específica de engajar os sentidos na atenção. Isto é, a experienciação de uma natureza revitalizante, capaz de alterar o modo pelo qual o corpo do caminhante é percebido por ele mesmo, é resultado da incorporação de determinadas sensibilidades.

Ao lançar mão de uma modalidade de experimentação da natureza - cenestesia - que não esteja restrita a um determinado sentido, procurase dar conta de descrições como a de Fábio, que elabora um relato fenomenológico pautado no modo pelo qual percebeu, naquela experiência, seu próprio corpo.

Por fim, vale destacar que o esforço em empreender uma descrição sobre as experiências das caminhadas entre os ecocaminhantes, a partir do delineamento de alguns modos somáticos de atenção, é uma tentativa de explorar outras possibilidades da abordagem antropológica. Trata-se de buscar apontar para o corpo não como um texto possível de ser lido, mas como a própria condição para que os sujeitos se constituam como tal.

(Recebido para publicação em novembro de 2010) (Aceito em janeiro de 2011)

\section{REFERÊNCIAS}

AMIROU, Rachid. Imaginaire touristic et sociabilités du voyage. Paris: Presses Universitaires de France, 1995.

BOURDIEU, Pierre. Razões prática: sobre a teoria da ação. 9.ed. Campinas: Papirus, 2008.

BAUBÉRO, Arnaud. La nature éducatrice. Ethnologie Française, Paris, PUF, v. 31, n. 4, p. 621-629, 2001.

CAMPBEL, Collin. A orientalização do Ocidente: reflexões sobre uma nova teodiceia para um novo milênio. Religião e Sociedade, Rio de Janeiro, ISER, v. 18, n. 1, p. 522, 1997.

CARVALHO, Isabel Cristina de Moura. A invenção ecológica: narrativas e trajetórias da educação ambiental no Brasil. 2.ed. Porto Alegre: Editora da UFRGS, 2002.

—. Paisagem, historicidade e ambiente: as várias naturezas da natureza. Confluenze: rivista di studi iboamericani, Bolongana,It, v. 1, p. 136-157, 2009.

; STEIL, Carlos Alberto. A sacralização da natureza e a 'naturalização' do sagrado: aportes teóricos para a compreensão dos entrecruzamentos entre saúde, ecologia e espiritualidade. Ambiente e Sociedade, Campinas, v. 11, n. 2, p. 289-305, 2008.

CSORDAS, Thomas J. Corpo/ significado/ cura. Porto Alegre: Ed. da UFRGS, 2008.

DUPRONT, Alphonse. Du sacré. Paris: Gallimard, 1987.

FERRY, Luc; GAUCHET, Marcel. Depois da religião. Rio de Janeiro: DIFEL, 2008.

- A nova ordem ecológica: a árvore, o animal e o homem. São Paulo: Ensaio, 1994.

FREY, Nancy Louise. Pilgrim Stories: on and off the road to Santiago. California: University of California Press, 1998.

GRABURN, Nelson. Tourism: the sacred journey. In: SMITH, V. (Ed.). Hosts and guests: the anthropology of tourism. 2.ed. Philadelphia: University of Pennsylvania Press, 1989. p. 21-36.

HERVIEU-LÉGER, Daniele. La religion pour mémoire. Paris: Éditions du Cerf, 1993.

. O peregrino e o convertido. Petrópoles: Vozes, 2008.

HOUAISS, Antônio; VILAR, Mauro de Salles. Dicionário Houaiss de Língua Portuguesa. Rio de Janeiro: Editora Objetiva, 2001

INGOLD, Tim. The perception of the environment. Essays in livelihood, dwelling and skill. London/New York: Routledge, 2000.

Jornada ao longo de um caminho de vida - mapas, descobridor-caminho e navegação. Religião e Sociedade, Rio de Janeiro, ISER, v. 25, n. 1, p. 76-110, 2005.

MAUSS, M. As técnicas do corpo. São Paulo: Cosac \& Naify, 2003 
MAGNANI, José Guilherme Cantor. O circuito neoesotérico na cidade de São Paulo. In: CAROZZI, Maria Júlia. A nova era no Mercosul. Petrópolis: Vozes, 1999.

. Mystica urbe. São Paulo: Prêmio Nobel, 1999b

MANIERI, Guilherme. Perfil dos praticantes de caminhadas ecológicas: um estudo exploratório- descritivo. 2008. Monografia (Conclusão de Curso)- UFRGS. Porto Alegre, 2008.

MERLEAU-PONTY, Maurice. Fenomenologia da percepção. Rio de Janeiro: Freitas Bastos, 1971. 2000 .

. O visível e o invisível. 4.ed. São Paulo: Perspectiva,

RIBEIRO, Gustavo Lins. Ambientalismo e desenvolvimento sustentado. Nova ideologia/utopia do desenvolvimento. Ciência da Informação, Brasília,DF, IBICT, v. 21 n. 1, jan/abr, p. 23-31, 1992.

SIQUEIRA, E.D. Ritual, turismo e cultura: o aeroporto do Galeão como lugar de passagem. In: CONGRESSO BRASILEIRO DE CIENCIAS DA COMUNICAÇÃO, 29., 2006, Brasília. Anais... São Paulo: Intercom, 2006. p. 1-15,

SMITH, Valene. (Ed.). Hosts and guests: the anthropology of tourism. 2.ed. Philadelphia: University of Pennsylvania Press, 1989

STEIL, Carlos Alberto. O sertão das romarias: um estudo antropológico sobre o santuário de Bom Jesus da LapaBahia. Petrópolis: Vozes, 1996.

A igreja dos pobres: da secularização à mística. ReTigião e Sociedade, Rio de Janeiro, ISER, v. 19, n. 2, p. 6176, 1999.

Peregrinação, romaria e turismo religioso: raízes etimológicas e interpretações antropológicas. In ABUMANSSUR, Edin Sued (Org.) Turismo religioso: ensaios antropológicos sobre religião e turismo. Campinas: Papirus, 2003. p. 29-51
Renovação Carismática Católica: porta de entrada ou de saída do catolicismo? Uma etnografia do Grupo São José, Porto Alegre (RS). Religião \& Sociedade, Rio de Janeiro, ISER,v. 24, n. 1, p. 11-36, 2004.

.Os demônios geracionais. A herança dos antepassados na determinação das escolhas e das trajetórias pessoais. In: DUARTE, L. F. D. H.; BARROS, Maria Luiza; LINS, Myriam; PEIXOTO, Clarice. Família e religião. Rio de Janeiro: Contra Capa, 2006. p. 219-240.

. Peregrinação. In: BORTOLLETO, Fernando Filho; SOUZA, José Carlos; KILPP, Nelson (Org.) Dicionário Brasileiro de Teologia. São Paulo: Aste, 2008, p. 782- 785

SOARES, Luiz Eduardo. O rigor da indisciplina. Rio de Janeiro: Relume-Dumara, 1994.

TONIOL, Rodrigo; STEIL, Carlos Alberto. Ecologia, nova era e peregrinação: uma etnografia da experiência de caminhadas na Associação dos Amigos do Caminho de Santiago de Compostela do Rio Grande do Sul. Debates do NER, Porto Alegre, UFRS, v. 11, n. 17, jan./jun., 2010.

TURNER, Victor. Dramas, campos e metáforas: ação simbólica na sociedade humana. Niterói: Ed. UFF, 2008.

THOMAS, Keith. O homem e o mundo natural: mudança de atitude em relação às plantas e aos animais, 1500-1800. São Paulo: Companhia das Letras, 2010.

URRY, John. O olhar do turista: lazer e viagens nas sociedades contemporâneas. São Paulo: SESC, 2001. 
ECOLOGY, BODY AND SPIRITUALITY: an ethnography of experiences of ecological hikes in a group of ecotourists

\author{
Carlos Alberto Steil \\ Rodrigo Toniol
}

This paper aims to study the experience of the ecohikers, a group that go on ecological hikes, betting on the cultivation of a spiritual, mental and physical well-being, hikes amidst nature. From the ethnography of the experience of hikers, one aims to investigate the experience of the trails as places full of restoring forces, energetic fluids for the health of body and soul. Based on the theoretical effort of a proposal that seeks, above all, to translate the phenomenology to the anthropological field and thus collapse dichotomies such as mind and body, nature and culture, subject and object, one tries to reflect on the therapeutic character of nature walks, understood by hikers not only as an exercise, but also as a means of access to matters of the soul.

KEYwORDS: ecotourism, new age, embodiment, body, nature walks.

\section{ÉCOLOGIE, CORPS ET SPIRITUALITÉ: une ethnographie des expériences de marche écologique dans un groupe d'éco-touristes}

\author{
Carlos Alberto Steil \\ Rodrigo Toniol
}

L'objectif de ce travail est d'étudier l'expérience des 'éco-marcheurs', un groupe de randonneurs écologiques qui, en faisant le pari d'un bien-être physique, mental et spirituel, fait des randonnées dans la nature. A partir de l'ethnographie de l'expérience des randonneurs, on fait une recherche sur l'expérience vécue sur les pistes considérées en tant que lieux remplis de forces régénératrices, de sources d'énergies bonnes pour la santé du corps et l'esprit. Fondé sur l'effort théorique d'une proposition qui vise, avant tout, à traduire la phénoménologie pour le champ anthropologique et permettre ainsi l'effondrement des dichotomies entre le corps et l'esprit, la nature et la culture, le sujet et l'objet, on essaie de réfléchir à l'aspect thérapeutique des marches, considérées par les randonneurs non seulement comme un exercice physique mais aussi comme un moyen d'accéder aux questions de l'âme.

MoTS-CLÉS: l'écotourisme, ère nouvelle, corporéité, corps, promenades écologiques.

Carlos Alberto Steil - Doutor em Antropologia Social. Professor do Programa de Pós-Graduação em Antropologia Social da Universidade Federal do Rio Grande do Sul (UFRGS). Realizou seu Pós-Doutorado na Universidade da Califórnia, San Diego UCSD. Pesquisador do CNPq. Coordenador do Núcleo de Cultura e Turismo (CulTus) e membro do Núcleo de Estudos da Religião (NER). Seu interesse de pesquisa se concentra nas áreas da antropologia da religião, da política e do turismo. Seu livro, O sertão das romarias: um estudo antropológico sobre o Santuário de Bom Jesus da Lapa, BA (1996), recebeu o premio Silvio Romero. É, ainda, autor de diversas coletâneas sobre temas de antropologia da religião e da política e de artigos publicados em periódicos científicos.

Rodrigo Toniol - Mestrando em Antropologia Social pelo Programa de Pós-Graduação em Antropologia Social da Universidade Federal do Rio Grande do Sul. Bolsista CAPES-REUNI. Estudante associado dos seguintes grupos de pesquisa (CNPq): Núcleo de Estudos da Religião (UFRGS), Núcleo de Pesquisa em Cultura Turismo e Sociedade (UFRGS) e Cultura, Ambiente e Educação (PUC/RS). Colabora no processo editorial do periódico Debates do NER. Desenvolve pesquisas nas áreas de religião, corpo, ecologia e turismo. 